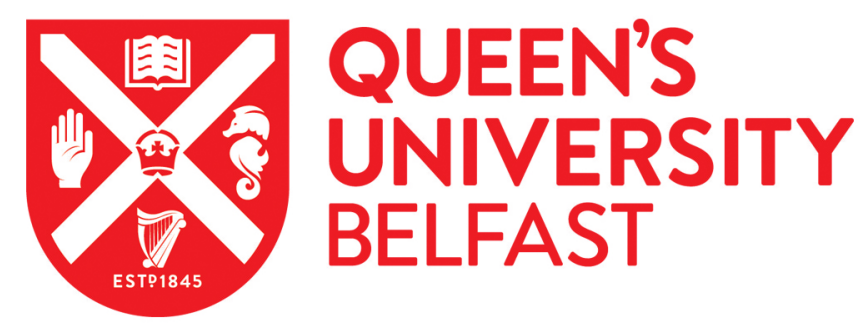

\title{
Abstract C215: Sensitivity of PTEN-deficient prostate carcinoma xenografts to ionizing radiation through inhibition of treatment-induced CXCL8 signaling
}

Armstrong, C. WD., Coulter, J. A., Walker, S., Kennedy, R. D., Prise, K. M., O'Sullivan, J. M., \& Waugh, D. JJ. (2013). Abstract C215: Sensitivity of PTEN-deficient prostate carcinoma xenografts to ionizing radiation through inhibition of treatment-induced CXCL8 signaling. In Proceedings of the AACR-NCI-EORTC International Conference (Vol. 12) https://doi.org/10.1158/1535-7163.TARG-13-C215

Published in:

Proceedings of the AACR-NCI-EORTC International Conference

Document Version:

Early version, also known as pre-print

Queen's University Belfast - Research Portal:

Link to publication record in Queen's University Belfast Research Portal

Publisher rights

(c) 2013 The Authors.

This work is made available online in accordance with the publisher's policies. Please refer to any applicable terms of use of the publisher.

\section{General rights}

Copyright for the publications made accessible via the Queen's University Belfast Research Portal is retained by the author(s) and / or other copyright owners and it is a condition of accessing these publications that users recognise and abide by the legal requirements associated with these rights.

Take down policy

The Research Portal is Queen's institutional repository that provides access to Queen's research output. Every effort has been made to ensure that content in the Research Portal does not infringe any person's rights, or applicable UK laws. If you discover content in the

Research Portal that you believe breaches copyright or violates any law, please contact openaccess@qub.ac.uk. 


\section{Abstract C215: Sensitivity of PTEN- deficient prostate carcinoma xenografts to ionizing radiation through inhibition of treatment-induced CXCL8 signaling.}

Chris WD Armstrong, Jonathan A. Coulter, Steven Walker, Richard D. Kennedy, Kevin M. Prise, Joe M. O'Sullivan and David JJ Waugh

\section{Abstract}

Background: CXCL8 signaling levels are elevated in localized high grade prostate cancer (CaP). We have shown exposure of CaP cells to chemical DNA-damaging agents potentiates CXCL8 signaling, which underpins an autocrine mode of therapeutic resistance. Data from in vitro and in vivo CaP models has shown loss of the tumor suppressor PTEN also increases expression of the pro-inflammatory chemokine CXCL8. Experiments were designed to determine whether exposure to ionising radiation (IR) selectively induced CXC-chemokine signaling in PTEN-deficient CaP cells, and to determine how CXCL8 signaling may modulate their radiosensitivity.

Methods: shRNA-directed strategies were used to establish cell-based models of CaP with differential expression of PTEN. These clonal (DU145) and heterogeneous (22Rv1) populations were subjected to IR under normal or hypoxic culture conditions. PTEN was reconstituted in PC3 cells and was driven by tetracycline-regulated expression of the gene. Changes in chemokine expression were analyzed by RT-PCR, immunoblotting and ELISA. Autocrine CXCL8 signaling was attenuated using siRNA to down-regulate gene expression of its receptors, CXCR1 and CXCR2. The effects of modulating chemokine signaling on cell viability following exposure to clinically-relevant doses of IR were assessed by colony formation assays, cell proliferation assays, and analysis of apoptosis and cellular senescence. The effect of CXCL8 signaling inhibition in vivo was determined using a PC3 xenograft model in SCID mice. The cell penetrating pepducin, x1/2pal-i3, was used to attenuate both CXCR1 and CXCR2 and tumor growth was assessed via caliper measurements.

Results: Exposure to IR (3 Gy) increased gene expression of CXCL8, CXCR1 and CXCR2 with PTEN-deficiency enhancing this response. Loss of PTEN expression differentially modulated the radiosensitivty of $\mathrm{CaP}$ cell lines: PTEN-depletion conferred relative radioresistance in DU145 cells but made 22RV1 cells more radiosensitive. However, the inhibition of CXCL8 signaling in all PTEN-depleted models resulted in consistently increased radiosensitivity (SER 1.2, 1.13, and 1.39 in DU145, 22RV1, and PC3 CaP cells, respectively; $\mathrm{p}<0.05$ ). Reconstitution of PTEN expression in PC3 cells abrogated the capacity of CXCL8 signaling blockade to confer radiosensitivity. The combination of IR and CXCL8 signaling-inhibition conferred increased apoptosis in DU145 cells (p53 mutant) but induced premature senescence in 22RV1 cells (p53 WT). In vivo, treatment of PC3 xenografts with x1/2pal-i3 combined with IR (3 Gy) resulted in a significant delay in tumor growth compared to control (median quadrupling time: 42 day x1/2pal-i3 \& IR vs. 32 day control \& IR; $\mathrm{p}<0.05$ ). Subsequent analysis of gene expression in these tumors confirmed that CXCL8 
signaling inhibition attenuated IR-induced expression of anti-apoptotic proteins Bcl-2 and CFLIP.

Conclusions: Our results demonstrate the role of treatment-induced CXCL8 signaling as a mechanism of resistance to IR in PTEN-depleted CaP cells. Inhibition of IR-induced CXCL8 signaling provides a novel therapeutic opportunity to enhance the radiosensitivity of PTENdepleted CaP cells. However, mechanistic results indicate that other genetic factors including p53 status dictate the resultant induction of treatment-induced apoptosis. 